\title{
Your Pain is in Your Head and that is Okay
}

\author{
Ashley Pfeiffer* and Craig Triplett \\ Department of Exercise Science, USA
}

*Corresponding author: Ashley Pfeiffer, Department of Exercise Science, DPT, 1200 University Street, Spearfish, SD, USA.

Received Date: October 03, 2019

Published Date: October 21, 2019

\section{Short Communication}

In my first year of practicing Physical Therapy, I was ready to tackle the world of pain. Twenty-five million people in the United States suffer from daily pain Nahin RL [1] and I wanted to tackle that number head on. I was fresh off of obtaining my doctorate degree and I was ready, or at least I thought I was, to tackle any pain that came my way. Non-radicular low back pain, no problem, manipulation and core stability exercises will get you back to work. Shoulder impingement problems don't stand a chance with me; a little manual therapy, scapular re-education, and cuff strengthening, and you will be back on the pitching mound. Achilles tendinosis you don't stand a chance; eccentric loading and tool-assisted soft tissue mobilization and you will be back to training for that marathon. So, it came as somewhat of a big surprise to me when I was not having $100 \%$ success and complete elimination of pain with everyone. What was I missing?

Yes, my patients would show some degree of improvement, but I always felt like I was missing something. Maybe the next continuing education course would have that missing tool or latest guideline that would help me get those difficult patients, especially ones with chronic pain, ultimately $100 \%$ pain-free. I went to several of these courses and improved my skills in all the physical areas but I still felt like I was selling my chronic pain patients short, and that is when I stepped back and really started asking my patient's questions as to how they viewed pain. The results were eye-opening.

What I found was that most of my patients had a huge amount of fear when it came to their condition. They went through their days cautious that the next move they made was going to elicit their pain. When I asked them what the definition of pain was, most replied that it was a message that their tissue of concern was not healthy and that pain levels correlated directly to the severity of their injury. Most of the people that responded this way also had an image or report to confirm that they had something "abnormal" such as degeneration in that specific tissue. When people are living in this much fear it is no wonder, I wasn't curing them of their symptoms with any of my multitude of tools I had learned in class. What I needed to do was slow down, listen to each person's individual story and educate them on pain and the reality that pain, when properly managed, can be a healthy and normal part of the human experience.

Some fabulous work from neuroscientists like Lorimer Moseley \& David Butler [2] gives us some great insight into our current understanding of pain which serves as my starting point when I educate patients on both acute and chronic pain. This is where I now start when I am educating my patients on their chronic pain. We have these messengers, called nociceptors, hanging out in all our tissues ready to send a report to the brain in regard to how hard something is pressing on them or to watch out if there is an extremely warm stimulus near you, but that is only part of the integrated system of pain. Those signals goes to the brain where it processes that information and decides what actions the body should take and whether or not that particular stimulus is normal or a threat. In this way, pain is absolutely necessary for our health and generally keeps us out of harmful situations by triggering a reaction from our body to stop, avoid, or prevent the threatening stimulus or tune it out if it poses no threat. The brain, in its simplest form, surveys our environment and the information we get from it and then acts to help us survive. In that manner, pain generated by the brain serves to protect us. However, the problem with chronic pain is that the brain is powerful. It can make the message have big red-hot warning signs on it and can make us react in over-thetop ways to situations that just aren't that catastrophic. It has the ability to take things like our mood, our thoughts, and our cultural situation all into account when deciding how much the proverbial pain bell will ring out to us.

The other piece I like to explain to my clients is the fact that the longer our system is in pain, the greater the response the brain will 
have to the messages it receives from the body. It is almost as though the body gets really good at sending a pain response because it has had so much practice at it. In this way, the pain system gets learned and is quick to respond to even an everyday small stimulus that, to a person not dealing with everyday pain, would not be considered painful enough to elicit a reaction. This can be incredibly frustrating and create large amounts of fear with everyday movements we all need to perform.

As mentioned earlier, twenty-five million people in the United States suffer from daily pain. That is twenty-five million people that are at risk for the pain system to become amplified and send over aggressive responses to non-threatening situations. If we as healthcare professionals and healers can help the patient understand this, then we are taking the first steps to take the control away from the pain and put it back with the patient. What I have found in my own practice is once I explain this without making the patient feel like they are "crazy" I have blasted through a huge barrier and we can begin to effectively move more and more. Mosely then gives us 3 steps to work through this process of retraining our pain system.

1. Rethink what pain is and where it comes from by recognizing its role in protection.

2. Actively re-engaging with your pain system in order to begin to retrain it.

3. Motion is lotion. The risk of inactivity is much greater than the risk of the activity. Get out there and start to move.
In summary when we as health professionals can slow down and spend time educating our patients on pain and how it operates, we can empower these individuals to lose the fear and gain control. When combining this with a holistic approach to health including not addressing just the pain but factors such as nutrition, sleep, being in the present state of mind and more, I believe we can make a huge difference in lowering the number of Americans dealing with daily pain. I now love to treat chronic pain and find so much joy in the ability to assist people down the long but prosperous journey towards less pain, more movement and intrinsic motivations, and overall increased well-being [3].

\section{Acknowledgement}

I would like to thank all my patients for their willingness to be open and vulnerable and allowing me to learn so much from them. I would also like to thank all the neuroscientists working diligently to create a world with less chronic pain.

\section{Conflict of Interest}

Author declares no conflict of interest.

\section{References}

1. Nahin RL (2015) Estimates of pain prevalence and severity in adults: United States, 2012. J Pain 16(8): 769-780.

2. Butler D, Moseley G (2013) Explain pain. $2^{\text {nd }}$ edn, Adelaide, Australia, pp. 1-133.

3. Louw A, Diener I, Butler DS, Puentedura EJ (2011) The Effect of Neuroscience Education on Pain, Disability, Anxiety, and Stress in Chronic Musculoskeletal Pain. Arch Phys Med Rehabil 92(12): 20412056. 